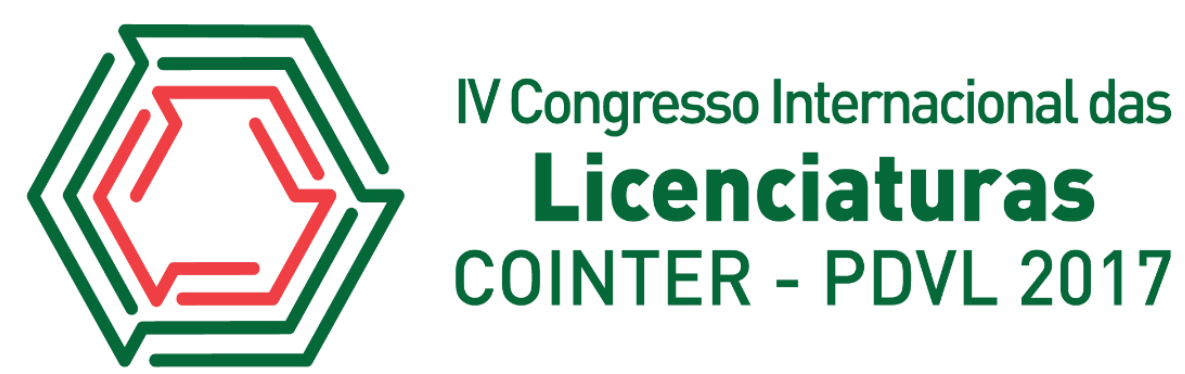

\title{
AGROECOLOGIA, RESGATE E VALORIZAÇÃO DAS SEMENTES DA PAIXÃO PARA AGRICULTURA FAMILIAR
}

\author{
Apresentação: Relato de Experiência \\ Marcilene Santos Silva ${ }^{1}$; Dalvilene Macena da Silva²; Estelita Tayná Medeiros da Silva ${ }^{3}$; \\ Milena Kelly Cruz da Silva ${ }^{4}$; Alexandre Eduardo de Araújo ${ }^{5}$
}

\section{Introdução}

Esse trabalho consistiu em um processo reflexivo, sobre a importância das sementes criolas e dos bancos de sementes comunitários no contexto de uma comunidade tradicional rural, com uma família de agricultores familiares do município de Arara-PB, a qual está inserido na área geográfica de abrangência do semiárido Brasileiro. A experiência se deu dentro de uma abordagem qualitativa alicerçada no pressuposto da agroecologia. Tendo em vista a necessidade de visibilizar práticas sustentáveis que fortalecem a agricultura familiar, esse relato tem o objetivo de fazer uma análise da importância da semente da paixão para o agricultor familiar e sistematizar o seu agroecossistema.

\section{Relato de Experiência}

"As sementes da paixão são as sementes dos nossos avós. Se adaptam e resistem, aqui as sementes têm 30, 40, até 60 anos sendo cultivadas na nossa cultura. São muito importantes para a nossa comunidade".

\section{Nadir Maria- Agricultora entrevistada}

O processo de erosão genética e expansão dos transgênicos no mundo, desde o final da revolução verde até os dias atuais têm provocado, em muitas regiões, o desaparecimento das sementes crioulas, que na região semiárida da Paraíba e de diversos estados brasileiros passaram a ser denominadas de sementes da paixão, a partir da organização dos agricultores e agricultoras familiares. As fortes relações que essas sementes guardam com a identidade cultural de diferentes povos e comunidades é expressa pelas variadas denominações que elas recebem: por exemplo, no estado da Paraíba, são chamadas de sementes da paixão, em Alagoas e em Goiás, trata-se das sementes da resistência, no Piauí são as sementes da fartura, em Minas Gerais, sementes da gente (CUNHA, 2013).

Para sistematização dessa experiência, foi realizada uma entrevista não-estruturada com a família da senhora Nadir Maria Ferreira da Silva, agricultora familiar, representante da comunidade,

\footnotetext{
${ }^{1}$ Licenciatura em Ciências Agrárias, CCHSA/UFPB, marcilene-1995@hotmail.com

${ }^{2}$ Licenciara em Pedagogia, CCHSA/UFPB, dalvilenemacena@homail.com

${ }^{3}$ Licenciatura em Ciências Agrárias, CCHSA/UFPB, taynasmedeiros@gmail.com

${ }^{4}$ Licenciatura em Ciências Agrárias, CCHSA/UFPB, milenacruz@hotmail.com

${ }^{5}$ Professor/Orientador, CCHSA/UFPB, alexandreeduardodearaujo@ hotmail.com
} 
associada, sindicalizada e dona de casa. Em seguida foi realizado uma visita técnica e travessia no agroecossistema desenvolvido na unidade de produção da família, considerado uma referência.

O Sítio da senhora Nadir está inserido na microrregião de Arara, na mesorregião do curimataú ocidental Paraibano e Semiárido Brasileiro. Tem uma área de seis hectares, onde trabalha em economia familiar, constituindo um subsistema dentro de um sistema maior. Nesta pequena propriedade é explorada a agricultura e a pecuária, além de haver na mesma, uma boa porção de vegetação nativa.

Os trabalhos com o banco de semente se iniciaram em 2008 de forma comunitária com incentivo de outros agricultores, por meio de visitas de intercambio proporcionadas pela AS-PTA (Assessoria e Serviços a Projetos em Agricultura Alternativa). Segundo dona Nadir Maria o banco de semente da comunidade tem como objetivo "Melhorar a renda, promover a autonomia dos agricultores, fortalecer a união do grupo envolvido e livrar-se dos atravessadores". As sementes são distribuídas em um sistema de empréstimo, onde dez litros são retribuídos com quinze litros. São armazenadas em garrafas PET e baldes plásticos e utilizado casca de laranja e pimenta para prevenir pragas. O banco comunitário armazena uma diversidade de sementes criolas.

Imagem 1.Sitio de da senhora Nadir Maria na comunidade de São Bento. ARARA, PB. ABRIL/2016

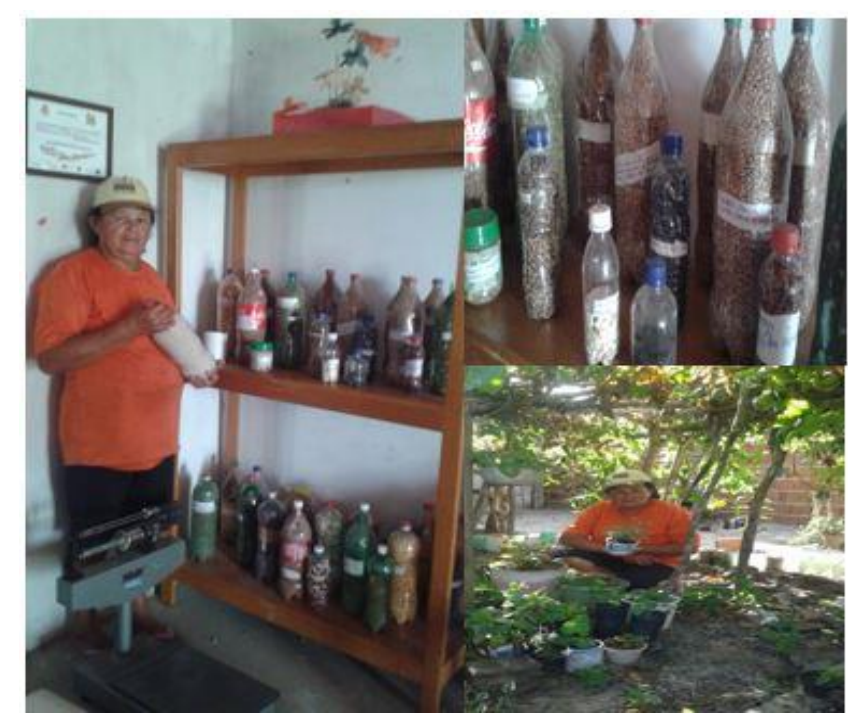

\section{Considerações}

O trabalho com o banco de semente e as práticas realizadas no agroecossistema do sítio de dona Nadir têm bons indicativos de sustentabilidade, devido ao manejo integrado de várias culturas, possibilitando um ambiente com maior biodiversidade, além de proporcionar benefícios ao solo e gerar renda o ano inteiro.

\section{Referências}

CUNHA, Flavia Londres da. Sementes da Paixão e as Políticas Públicas de Distribuição de Sementes na Paraíba.2013. 184 f. Dissertação (Mestrado) - Curso de Pós-graduação em Práticas em Desenvolvimento Sustentável, Universidade Federal Rural do Rio de Janeiro Instituto de Florestas, Seropédica, RJ, 2013. Cap. 09. 